\title{
THE EFFECT OF FINANCIAL AND NON-FINANCIAL PERFORMANCE ON REGIONAL COMPETITIVENESS OF BUNGO DISTRICT WITH CAPITAL EXPENDITURE AND BUDGET GOVERNANCE AS INTERVENING
}

\author{
By \\ Herawati $^{1}$, Syamsurijal Tan ${ }^{2}$, Sri Rahayu ${ }^{3}$, Syahmardi Yacob $^{4}$ \\ ${ }^{1}$ Muara Bungo University \\ ${ }^{2,3,4}$ Jambi University \\ Email: ${ }^{1}$ herawatinaufabel@gmail.com
}

\begin{abstract}
Article Info
Article History:

Received:13-10-21

Revised : 14-11-21

Accepted: 27-11-2021

ABSTRACT

This study aims to determine the effect of financial and non-financial performance, capital expenditure, budget management on regional competitiveness. Second, this study also determines the impact of financial and non-financial performance on regional competitiveness through capital expenditures and budget management in the Bungo Regency. Primary data were collected through direct interviews with respondents with predetermined criteria and processed using Structural Equation Model analysis with PLS. The results study found only financial and non-financial

Keywords:

Financial Performance, Nonfinancial Performance, Capital

Expenditure, Budget

Management, Regional performance and budget management had a significant effect on regional competitiveness, while capital expenditure had no effect. This study also found that financial and non-financial performance affects regional competitiveness through budget management, but it had no effect if capital expenditures were intervening.
\end{abstract}

Competitiveness

This is an open access article under the CC BY-SA license.

Corresponding Author:

Herawati

Muara Bungo University

Email: herawatinaufabel@gmail.com

\section{INTRODUCTION}

Competitiveness is the ability of a region to meet competition while maintaining a high level of income that results in sustainable regional prosperity. Competitiveness is the ability to generate high-level income and employment opportunities while remaining open as a developing country. Indonesia strives the expansion province and district governments to considerations the rights and responsibilities as an autonomous region. These responsibilities are related to development refer to the welfare of the community in each of these fields. The granting authority and region responsibility had regulated in UU No 32/2004 concerning Regional Government.

The regional autonomy implementing, provincial and district governments were required to have greater regional financial independence so the higher the level of financial independence of a region, the region can provide higher quality public services, invest in long-term development, etc. The central government gives the correct regional autonomy to local governments to manage their regional interests so that the community is more prosperous.

Budget performance is an instrument used by the DPRD to develop the performance of district heads, the instrument used by regional to developt work units under regional control as executive managers. Financial performance is prominent to know whether a program has been efficiently and effectively implemented (Mardiasmo, 2014). The paradigm of regional financial management, especially in developing districts, has undergone a fundamental change since the implementation of regional autonomy in 2001. UU no. 32 and 33/ 2004 is the regional autonomy implementation providing opportunities to optimize the potential, both regarding human resources and other resources.

Improving the region's economy is one of the goals achieved through good financial performance. Financial performance is a performance measure that uses financial indicators.Financial performance analysis is assessing 
performance by conducting various analyzes to obtain an effective and efficient financial position. Financial analysis is the role attempt to identify characteristics based on financial statements.

Based on the Regulation of the Minister of Home Affairs No. 21 of 2011 article 1 paragraph 37 (second amendment of Permendagri No. 13 of 2006), financial performance is activities result and programs that will achieve in connection with the use of the budget with measurable quantity and quality. That meant as the financial performance of the regional government, in this case, is the increase in the achievement of work in the field of regional finance includes the budget and the realization of PAD by using financial indicators determined through a policy or statutory provision from one budget period in government organizations to measure performance there are several measures of performance.The local government's efforts in exploring regional financial capabilities can be seen from the regional financial performance as measured by the government's financial ratio analysis to maintain and improve its success from one period to the next. Increasing capital expenditure in Bungo Regency increases regional competitiveness through an increase in GDP, shown in table 1.

Table 1. Bungo Regency GRDP and Capital Expenditure Data 2015-2019

\begin{tabular}{ccccc}
\hline Year & APBD & \% & Capital Expenditure & \% \\
\hline 2015 & $10,334,000,000$ & - & $13,588,595,700$ & - \\
\hline 2016 & $10,891,000,000$ & 5.39 & $12,754,403,311$ & -6.14 \\
\hline 2017 & $11,510,000,000$ & 5.68 & $17,461,466,843$ & 36.91 \\
\hline 2018 & $12,052,000,000$ & 4.71 & $15,470,250,000$ & -11.40 \\
\hline 2019 & $12,576,000,000$ & 4.35 & $18,471,253,434$ & 19.40 \\
\hline
\end{tabular}

Source: BPS Indonesia (www.bps.go.id), 2020

Table 1 shows the increase in the regional competitiveness of the Bungo Regency through an increase in capital expenditure. The increase in competitiveness the GRDP value of Bungo Regency continues to increase every year. The highest GRDP in 2019 with a GRDP value of Rp. 12,576,000,000. The highest capital expenditure in 2019 with a value of Rp. 18,471,253,434, although capital expenditure decreased in 2018.

The APBD Description and Analysis Report published by the Directorate General of Fiscal Balance in 2011-2015 states that Jambi Province is one of the provinces that still budget for capital expenditures with proportions below the national average percentage. Its means that Jambi Province is one of the provinces that has not given sufficient attention to encouraging economic growth, especially the economy district's growth and cities. Bungo Regency is one of the regencies with a high allocation of capital expenditure and has an impact on increasing regional competitiveness.

Several studies show that the allocation of capital expenditures to local governments could influence regional financial performance Hidayat (2013) shows the allocation of capital expenditures made by district governments in East Java Province influenced by financial performance. Another study by Martini and Dwirandra (2015) researched districts in Bali Province showed that financial performance affected the allocation of capital expenditures, especially ratios. Similar studies Pilat\&Morasa (2017) found that the relationship pattern level of regional independence was on the instructive criteria. The independence of the Manado City Government is in the regional financial capacity is still very low in meeting the funding needs for the implementation of government tasks, development, and community social services. Based on the results of the calculation and analysis of Regional Financial Capability, it concluded that the condition of Manado City's financial capacity is still not ideal.

Management of regional financial performance when viewed from a non-financial perspective, Bungo Regency can develop and compete fairly with other regions. Real efforts are needed from all regional parties, especially DPRD and community participation in developing their regions. The higher community participation in paying taxes and regional have an impact on increasing the competitiveness of the Bungo Regency area compared to other areas in Jambi Province.The financial and non-financial performance viewed from the side of human resources the number of human resources working in the government, political and academic sectors is still very lacking, will affect the effectiveness of regional financial performance and will have an impact on reducing regional competitiveness in Bungo Regency so that the research objectives for the analysis of the influence of the financial performance and non-financial performance on capital expenditures and budget governance and regional competitiveness of Bungo Regency.

This study aims to determine the effect of financial and non-financial performance, capital expenditures, budget management on regional competitiveness. Second, the impact of financial and non-financial performance on the regional competitiveness through capital expenditures and budget management in the Bungo Regency. The hypotheses of this research are 1) That financial and non-financial performance has a significant effect on regional competitiveness. 2) capital expenditures have a significant effect on regional competitiveness. 3) budget management has a significant effect on regional power. 4) financial performance and non-financial performance have a significant 
International Journal of Social Science (IJSS)

Vol.1 Issue.4 December 2021, pp: 347-354

ISSN: 2798-3463 (Printed) | 2798-4079 (Online)

DOI: https://doi.org/10.53625/ijss.v1i4.713

effect on regional competitiveness through capital expenditures. 5). financial performance and non-financial performance have a significant effect on regional competitiveness through budget management.

\section{METHOD}

This study uses two methods, namely descriptive analysis, and quantitative analysis. Furthermore, because of the complex form of modeling, use Structural Equation Modeling (SEM) with Smart PLS tools. The population study is the total population in Bungo Regencies according to BPS Bungo data in 2019 as many as 374,337 people. The number of samples used on the number of indicators in this study 16 indicators, at least five times the number of indicator variables (Ferdinand, 2014), so a minimum of $16 \times 5$ or 80 samples is needed. However, in the Chi-Square test, the SEM model is the sensitive samples number the criteria proposed by Hair et al. (2010) using the Maximum Likelihood Estimation (MLE) technique. The samples number to MLE ranges from 100-200. Therefore, the samples number in this study was 110 samples with the source of research data coming from questionnaires prepared and given to respondents individually. The respondents are government employees, politics, academics, the general public with religious leaders and community leaders.

\section{RESULTS AND DISCUSSION}

The research help of enumerators who had trained in the data collection process, including how to input the results of activities through the recapitulation of research results, so that errors will not occur. Characteristics of respondents based on the respondent's age, gender, education, occupation, and number of family members can be shown in table 2: members can be presented in table 2:

Tabel 2. Distribution of Respondent by Age, Gender, Education and Occupation in 2020

\begin{tabular}{|c|c|c|c|}
\hline characteristics & Group & Amount & Percentage \\
\hline \multirow{5}{*}{ Age } & $29-40$ & 13 & 11,81 \\
\hline & $41-50$ & 26 & 23,63 \\
\hline & $51-60$ & 38 & 34,54 \\
\hline & $61-70$ & 17 & 15,45 \\
\hline & $70>$ & 6 & 5,45 \\
\hline \multirow{2}{*}{ Gender } & Man & 72 & 65,45 \\
\hline & Woman & 38 & 34,54 \\
\hline \multirow{4}{*}{ Education } & Diploma III & 2 & 1,81 \\
\hline & Bachelor & 36 & 32,72 \\
\hline & Magister & 51 & 46,36 \\
\hline & Doctor & 21 & 19,09 \\
\hline \multirow{6}{*}{ Occupation } & Political & 15 & 13,63 \\
\hline & Local Civil & 20 & 18,18 \\
\hline & Akademy & 35 & 31,81 \\
\hline & Representative Council & 15 & 13,63 \\
\hline & Public Figure & 25 & 22,72 \\
\hline & Jumlah & 110 & 100,0 \\
\hline
\end{tabular}

Source:Quetionare,(2020)

Based on table 2, from a total of 110 respondents, it is known that respondents aged 51-60 years still dominate in this study ranging from 34.54. When viewed from the gender, male respondents were dominated by 72 people $(65.45 \%)$, while the remaining 38 respondents were female $(34.54 \%)$. Specifically, the education level of the respondents with the most Master's education is 51 people $(46.36 \%)$, while the occupation level shows that the profession as academics is $35(31.81 \%)$ the most.

Empirical Findings and Analysis of Research Results

Based on the Outer Measurement Model (Measurement Model) using validity and reliability. Two types of validities in SEM-PLS, namely convergent validity (loading factor and AVE) and discriminant validity (FornellLarcker and Crossloading). Meanwhile, reliability was measured using composite reliability and Cronbach's alpha values. Convergent validity using (1) loading factor and (2) average variance extracted (AVE). The AVE value is at least 0.5 . Convergent validity measures the validity of the reflective indicator as a measure of the latent variable can 
see from the loading factor value of each indicator variable. In other words, the loading factor shows the correlation between the indicator and its construct, the indicator valid if it has a loading factor value above 0.70. (Sarwono, 2014). This value describes convergent validity in that one latent variable can explain more than half of the variance of the indicator in the average. The model used in this section is a revised model after each indicator research variable that is not valid convergently validity (loading factor) removed from the model.The detailed operational research model is as shown in the following picture:

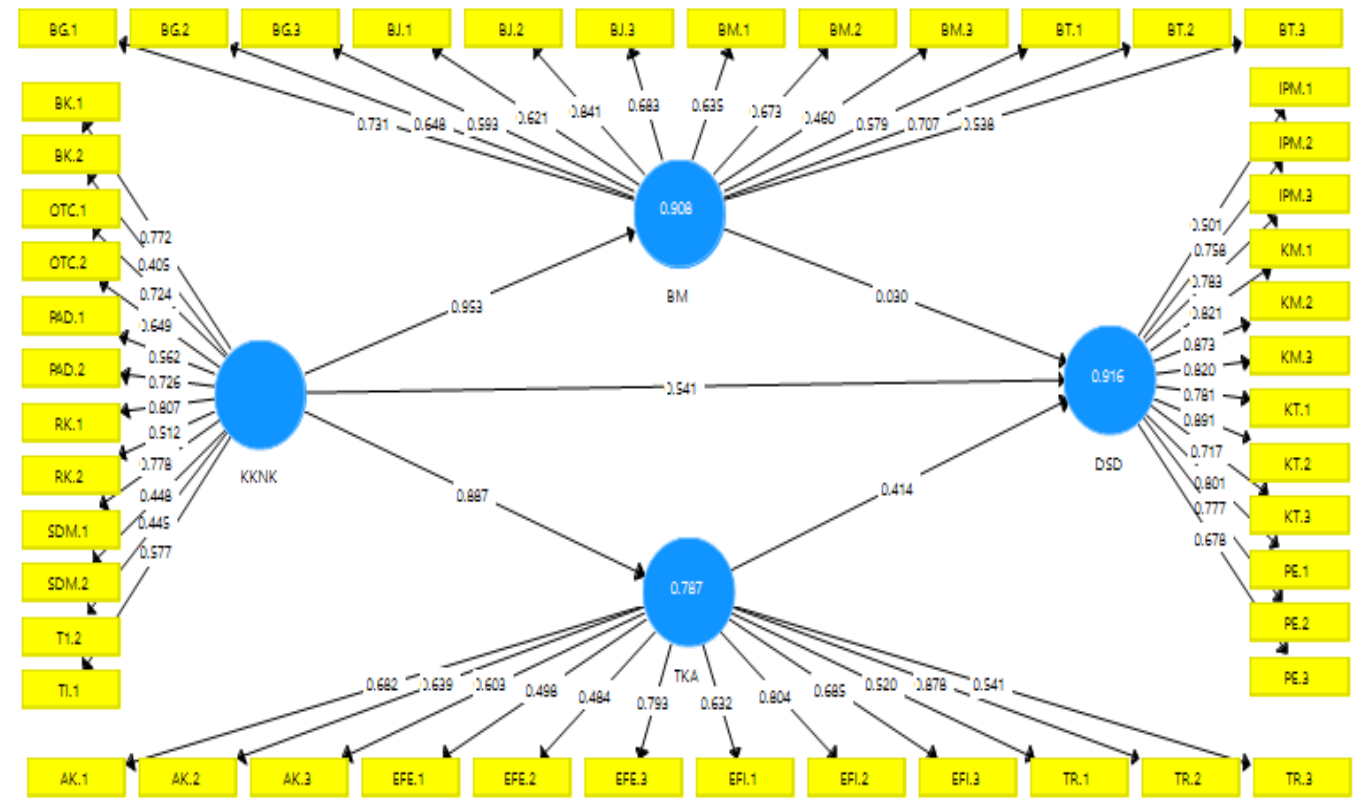

Graph 1. Research Operational Model

(Source: Output SmartPLS 3.3.2(2020)

Based on Figure 1, there are 7 indicators whose loading factor value is less than 0.7 , then the operational research model becomes as follows:

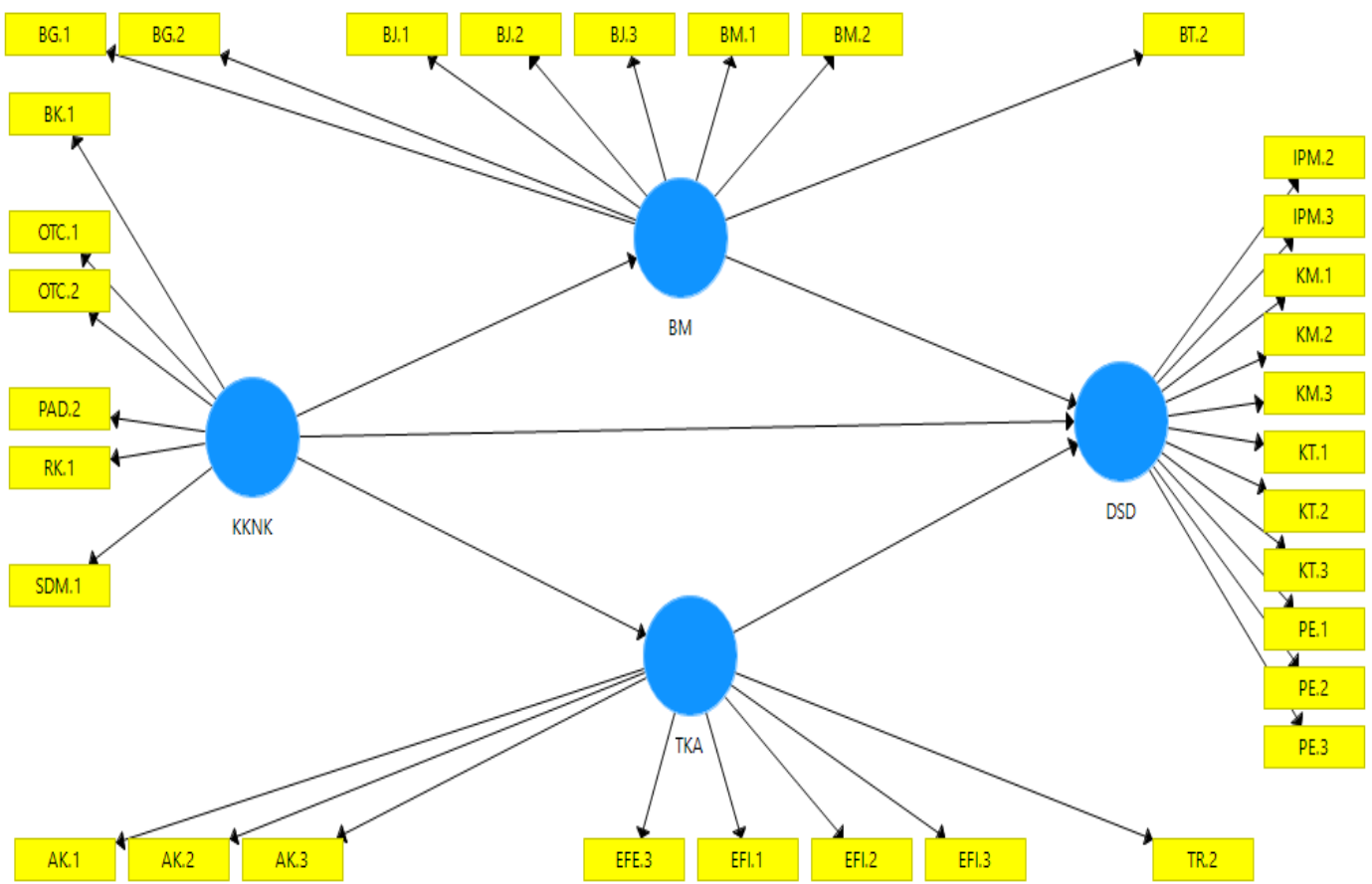

Graph 2. Valid Structural Model (which 7 indicators have been issued)

Source: SmartPLS 3.3.2 output (2020) 
International Journal of Social Science (IJSS)

Vol.1 Issue.4 December 2021, pp: 347-354

ISSN: 2798-3463 (Printed) | 2798-4079 (Online)

DOI: https://doi.org/10.53625/ijss.v1i4.713

Based on Figure 2, the results of the analysis of indicators that have been analyzed through SEM in the image above are obtained as a whole each indicator that meets the requirements for further testing with the loading factor value. Furthermore, the reliability test was two ways, namely based on the value of Cronbach's Alpha and Composite Reliability. The instrument is reliable if the Cronbach's alpha $>0.6$ and the value of composite reliability 0.8. Based on Table 4, that the value of Cronbach's alpha financial and non-financial performance, regional competitiveness, budget governance, and capital expenditure is more than 0.6 , this indicates that the instruments used to measure the financial and non-financial performance, capital expenditures, budget governance, and regional competitiveness are reliable.

Table 5.Reliability of research indicators (Cronbach's Alpha, Composite Reliability and Average Variance Extracted/AVE)

\begin{tabular}{cccc}
\hline Kontruct & $\begin{array}{c}\text { Cronbach's } \\
\text { Alpha }\end{array}$ & $\begin{array}{c}\text { CompositeReliab } \\
\text { ility }\end{array}$ & $\begin{array}{c}\text { Average } \\
\text { VarianceExtracted(A } \\
\text { VE) }\end{array}$ \\
\hline $\begin{array}{c}\text { Financial and Non-financial } \\
\text { Performance }\end{array}$ & 0.869 & 0.894 & 0.514 \\
\hline Capital Expenditure & 0.942 & 0.95 & 0.634 \\
\hline Budget Management & 0.88 & 0.911 & 0.636 \\
\hline Regional Competitiveness & 0.871 & 0.9 & 0.536 \\
\hline
\end{tabular}

Source: Smart PLS 3.3.2 output (2020)

Measurement of Inner Model (Structural Model)

Structural model test was conducted to test the latent construct relationship. There are several tests, namely: R-Square (R2), Effect Size (f Square), Q2, and GoF. The following is a more detailed analysis of each inner model test in tables 5 and 6 .

Tabel 5. R square Value

\begin{tabular}{cc}
\hline Konstruk & RSquare \\
\hline Capital Expenditure & 0.836 \\
Budget Management & 0.862 \\
Regional Competitiveness & 0.770 \\
\hline
\end{tabular}

Sumber: output Smart PLS 3.3.2 diolah (2021) Tabel 6. Effect Size (F2) Value

\begin{tabular}{ll}
\hline \multicolumn{2}{c}{ Daya saing daerah(DSD) } \\
\hline KK-NK & 0,001 \\
\hline Capital Expenditure & 0.097 \\
\hline Budget Management & 0.493 \\
\hline
\end{tabular}

Sumber:

PLS 3.3.2 diolah (2021)

output Smart

Based on table 5 R-Square, all constructs value more than 0.67 is a strong category, Chin (1998). Based on table 6, the relationship between financial and non-financial with regional competitiveness is 0.002 , which indicates that financial and non-financial performance has a weak influence on regional competitiveness. While f2, the relationship the capital expenditure and regional competitiveness is 0.097 , the capital expenditure has a weak influence on regional competitiveness. The relationship between budget governance and regional competitiveness is 0.493, the budget governance has very strong influence on regional competitiveness, Hair et al. (2014).The last part of the inner model test is to find the Goodness of Fit (GoF) value. In contrast to CB-SEM, the GoF value in SEMPLS must calculate manually. According to the formula of Tenenhaus and et al. (2004) namely:

$\mathrm{GoF}=\sqrt{ } A V E \times R^{2}$.

\begin{tabular}{|c|c|}
\hline $\mathrm{BM}$ & {$[0,514 \times 0,835=0,65$} \\
\hline GoFDSD & $=\sqrt{0} 0,634 \times 0,858=0,7375$ \\
\hline GoFTKA & $=\sqrt{ } 0,536 \times 0,768=0,6415$ \\
\hline
\end{tabular}

According to Tenenhaus and et al. (2004), small GoF $=0.1$, medium GoF $=0.25$ and large $\mathrm{GoF}=0.38$. Based on the calculations above, it shows that the GoF value of the BM, DSD, and TKA constructs is greater than 0.38 and the GOF value of the constructs means that the structural model formed meets the goodness or the structural model that is good, fits the field conditions and can be used to predict the ability buy health services so that the construction model is acceptable. R2, f2, Q2, and GoF tests, the structural model formed is sturdy or continued at the 
next stage. Testing this hypothesis is part of measuring the inner model. Two things in hypothesis testing, the estimation of the path coefficient and t-statistics or p-values the significant effect endogenous on exogenous constructs, which indicators have contribution in reflection or forming latent constructs. Path Coefficient Estimation was carried out by Bootstrapping procedure, with the results of table 7:

Table 7. The results of bootstrapping direct and indirect effects

\begin{tabular}{cccccc}
\hline Direct Influence & $\begin{array}{c}\text { OriginalS } \\
\text { ample(O) }\end{array}$ & $\begin{array}{c}\text { Sample } \\
\text { Mean(M) }\end{array}$ & $\begin{array}{c}\text { StandardDeviat } \\
\text { ion(STDEV) }\end{array}$ & $\begin{array}{c}\text { TStatistics }(\mid \mathbf{O} / \mathbf{S} \\
\text { TDEV } \mid)\end{array}$ & $\begin{array}{c}\mathbf{P} \\
\text { Values }\end{array}$ \\
\hline KKNK $\square$ D S D & 0.302 & 0.274 & 0.118 & 2.562 & 0.011 \\
\hline BM $\square$ DSD & 0.034 & 0.051 & 0.145 & 0.233 & 0.816 \\
\hline TKA $\square$ DSD & 0.62 & 0.633 & 0.159 & 3.896 & 0,000 \\
\hline \multirow{2}{*}{ Indirect Influence } & $\begin{array}{c}\text { OriginalS } \\
\text { ample(O) }\end{array}$ & $\begin{array}{c}\text { Sample } \\
\text { Mean(M) }\end{array}$ & $\begin{array}{c}\text { StandardDeviat } \\
\text { ion(STDEV) }\end{array}$ & $\begin{array}{c}\text { TStatistics }(\mid \mathbf{O} / \mathbf{S} \\
\text { TDEV } \mid)\end{array}$ & $\begin{array}{c}\text { P } \\
\text { Values }\end{array}$ \\
\hline KKNK $\square \mathrm{BM} \square \mathrm{DSD}$ & 0.031 & 0.047 & 0.134 & 0.231 & 0.817 \\
\hline $\mathrm{KKNK} \square \mathrm{TKA} \square \mathrm{DSD}$ & 0.544 & 0.561 & 0.153 & 3.551 & 0,000 \\
\hline
\end{tabular}

\section{CONCLUSIONS}

\section{Conclusions}

Based on the results of the path estimation test, it can be interpreted in each research hypothesis as follows:

The Influence of Financial and Non-Financial Performance on Regional Competitiveness.

Based on the results of bootstrapping the direct influence and indirect effect on the statement stated in hypothesis 1 , a structural model equation is produced, stating that the t-statistics value of the coefficient of the mainline structural model (original sample O) KKNK to DSD is 2,562 >1.96 ( $\mathrm{Z}$-value). normal score for a $=0.05$ ) and P-value of $0.011<0.05$. This value indicates that there is a direct influence of financial and non-financial performance on regional competitiveness in the Bungo Regency.

Effect of Capital Expenditure on Regional Competitiveness.

Based on the results of bootstrapping the direct and indirect effects on the statements listed in hypothesis 1, which resulted in the structural model equation, stated that the t-statistics coefficient of the main path structural model (original sample $\mathrm{O}$ ) BM to DSD was $0.233<1.96(\mathrm{Z}$ value - normal score for a $=0.05$ ) and P-value of 0.816 $<0.05$. This value indicates that there is no direct effect of capital expenditure on regional competitiveness in the Bungo Regency.

\section{The Effect of Budget Governance on Regional Competitiveness}

The results of bootstrapping direct and indirect effects on the statements listed in hypothesis 1 generated by the structural model equation, stating that the t-statistical coefficient of the main path structural model (original sample O) BM to DSD is $3.896>1.96(Z$-score normal for $\mathrm{a}=0.05)$ and a P-value of $0.000<0.05$. This value indicates the direct influence of budget governance on regional competitiveness in the Bungo Regency.

Effect of financial and non-financial performance on regional competitiveness through capital expenditures.

The results of bootstrapping direct and indirect effects on the statements listed in hypothesis 4 results in the structural model equation, stating that based on the original sample value $(O)$ the indirect effect of KKNK on DSD through BM as an intervening variable has t-statistics of $0.231<1,96$ and sig value of $0.817<0.05$ indicates that the relationship between the three variables is not significant. The capital expenditure is not able to mediate the relationship between financial and non-financial performance with regional competitiveness. The fourth hypothesis is the financial and non-financial performance does not directly affect regional competitiveness through capital expenditure as an intervention variable, which is rejected.

Effect of financial and non-financial performance on regional competitiveness through budget governance

The results of bootstrapping direct and indirect effect on the statements listed in hypothesis 4 results in the structural model equation, stating that based on the original sample value $(\mathrm{O})$ the indirect effect of KKNK on DSD through TKA as an intervening variable has t-statistics of 3,551>1, 96 and the sig value of $0.000<0.05$ which indicates that the relationship between the three variables is significant. It means that budgetary governance can mediate the relationship between financial and non-financial performance with regional competitiveness. So the fifth research hypothesis states that financial and non-financial performance has no direct effect on regional competitiveness through budget management as an intervention variable, is accepted. 
International Journal of Social Science (IJSS)

Vol.1 Issue.4 December 2021, pp: 347-354

ISSN: 2798-3463 (Printed) | 2798-4079 (Online)

DOI: https://doi.org/10.53625/ijss.v1i4.713

\section{Conclusion}

The conclusions research is following statements:

1. Financial and non-financial performance have contributed to increasing regional competitiveness in MuaroBungo Regency because the leadership style in making local government policies to economic growth is appropriate.

2. Capital expenditures do not contribute to increasing regional competitiveness in MuaroBungo Regency. Capital expenditures from DAU, DAK, and other sources of funds are inefficient and irresponsible, a lot of inappropriate use of capital expenditure funds and capital expenditures do not provide benefits to regional competitiveness.

3. Budget governance is one of the determining factors for increasing regional competitiveness in the MuaroBungo Regency because budget governance has a significant effect on regional competitiveness due to effective and efficient budget management.

4. Financial and non-financial performance does not impact regional competitiveness through capital expenditure in MuaroBungo Regency because budget governance has significant on competitiveness and effective and efficient budget management.

5. Financial and non-financial performance are determinants of increasing regional competitiveness through budget management in Muaro Regency because Bungo's human resources quality and work culture are good so KKNK contributes to DSD through budget management.

\section{RECOMMENDATIONS}

Recommendations in the form of suggestions from research studies are:

1. In principle, financial and non-financial performance has a significant influence on regional competitiveness but the non-optimal financial and non-financial performance in Bungo Regency does not significant on regional competitiveness.

2. There needs to be special attention to government capital expenditures such as evaluation and control activities regularly per semester so that the target of capital expenditure is precise.

3. The effectiveness and efficiency of budget management need to be improved in the future will be good budget governance in the Bungo Regency government.

\section{REFERENCES}

[1] Abdullah, S., dan Asmara, J. A. (2004). PerilakuOportunistikLegislatifdalamPenganggaran Daerah: BuktiEmpirisatasAplikasi Agency Theory di SektorPublik. Emerald Insight 15, 578-593.

[2] Adi, (2006). Hubungan Antara PertumbuhanEkonomi Daerah, Belanja Pembangunan danPendapatanAsli Daerah (StudiPadaKabupatenJawadan Bali). Simposium Nasional Akuntansi.

[3] Ardhini, A., danHandayani, S. (2011). PengaruhRasioKeuangan Daerah terhadapBelanja Modal untukPelayananPublikdalamPerspektifTeoriKeagenan. JurnalEkonomi Pembangunan.

[4] Arsyad, Lincolin. (1999). PengantarPerencanaandan Pembangunan Ekonomidaerah. BPFE: Yogyakarta.

[5] Arsyad, Lincolin. (2010). Ekonomi Pembangunan. EdisiKelima. BP STIE YKPN: Yogyakarta.

[6] Azwar, (2007). MetodePenelitianPustaka. PustakaPelajar: Yogyakarta.

[7] Bastian, Indra. (2001). AkuntansiSektorPublik di Indonesia. EdisiPertama. BPFE: Yogyakarta

[8] BPS KabupatenBungo. (2019). JumlahPendudukProvinsi Jambi. wwwBPSProvinsi Jambi.

[9] Canning, David, and Peter Pedroni. (2004). Infrastructure and Long Run Economic Growth.University of Belfast.

[10] De Bruijn, H. (2002). Performance Measurement in the Public Sector: Strategies to Cope with the Risks of Performance Measurement. Emerald Insight 15, 578-593.4. Ejurnal EP Unud, 5[7]:925-947

[11] Hidayat, M. F. (2013). AnalisisPengaruhKinerjaKeuangan Daerah terhadapAlokasiBelanja Modal (StudipadaKabupatendan Kota di JawaTimur).

[12] Junaidi. (2015). Ekonometrika 1. FakutasEkonomidanBisnisUniversitas Jambi.

[13] Kasmi, dkk. (2017). PengaruhPendapatan Daerah danKinerjaKeuanganTerhadapPertumbuhanEkonomidanKesejahteraanMasyarakatKaupaten/Kota Provinsi Lampung. JurnalKeuangandanBisnis.

[14] Kuncoro, Mudrajat. (2004). Otonomidan Pembangunan Daerah. Erlangga: Jakarta.

[15] Kusuma, Hendra. (2016). DesentralisasifiskaldanPertumbuhanEkonomi. JurnalEkonomiKuantitatifTerapan. 9 (1), 1-11.

[16] Mahmudi, (2010). ManajemenKinerjaSektorPublik. EdisiKedua. UPP STIM YKPN: Yogyakarta.

[17] Mahmudi. (2016). AnalisisLaporanKeuanganPemerintahan Daerah. EdisiKedua. UPP STIM YKPN: Yogyakarta.

[18] Mankiw, N. Gregory. (2006). PengantarTeoriEkonomiMakro. SalembaEmpat: Jakarta.

[19] Mankiw, N. Gregory., David Romer, David N Weil. (1962). A Contribution To The Empirics Of Economic Growth, TheQuartely Journal Of Economics. 107(02).

[20] Mankiw, N. Gregory. (2003). PengantarEkonomi. Jakarta: Erlangga.

[21] Mardiasmo. (2014). OtonomidanManajemenKeuangan Daerah. Yogyakarta: Andi. 
[22] Pilat, J. J., \& Morasa, J. (2017). Analisis Rasio Keuangan Anggaran Pendapatan dan Belanja Daerah (APBD) Kota Manado Untuk Menilai Kinerja Keuangan Pemerintah Kota Manado Tahun Anggaran 2011-2015. Jurnal Accountability, 06(01), 45-56. https://doi.org/https://doi.org/10.32400/ja.16026.6.1.2017.45-56

[23] PeraturanMenteriDalamNegeriNomor 13 Tahun 2013 pasal 3. TentangKekuasaanPengelolaanKeuangan Daerah Kabupaten.

[24] Permendagri No. 13 Tahun 2006. TentangKeuangan Daerah

[25] PermendagriNomor 13 Tahun 2006 ( pasal 18, ayat(1 dan 2). TentangPengeluaran Daerah Pembiayaan Daerah.

[26] Porter, E, Michael. (2010). EkonomiUntuk Daerah. PenerbitErlangga Jakarta.

[27] PP 23 Tahun 2003, PP 58 Tahun 2005, PMK No.45 Tahun 2006, dan PMK No. 72 Tahun 2006. KebijakanFiskalSecaraNasional .

[28] Puspitasari, Lindri, Ni Luh, dkk. (2015). PengaruhBelanja Modal TerhadapPertumbuhanKinerjaKeuangan Daerah DenganPendapatanAsli Daerah SebagaiVariabel Intervening (StudiKasus Di KabupatenBuleleng). JurnalAkuntansi. 3(1).

[29] Rahardjo, Adisasmita. (2005). EkonomiUntuk Daerah. PenerbitErlangga: Jakarta.

[30] Rantanen, H., Kulmala, H., Lönnqvist, A., danKujansivu, P. (2007). Performance Measurement Systems in the Finish Public Sector. Emerald Insight 20, 418-419.

[31] Sianturi, A., Sjamsuddin, S., danDomai, T. (2014). PeranPendapatanAsli Daerah dalamMenunjangDesentralisasiFiskaldan Pembangunan Daerah (StudipadaDinasPendapatan Kota Batu). JurnalAdministrasiPublik(JAP), 557.

[32] Sugiyono, (2012). MetodePenelitianBisnisKuantitatif, Kualitatit, dan R\&D. Bandung: PT. AlfabetaCipta.

[33] Sularso, H., danRestianto, Y. M. (2012). PengaruhKinerjaKeuanganterhadapAlokasiBelanja Modal danPertumbuhanEkonomiKabupaten/Kota di Jawa Tengah. AkuntansiSektorPublik. Andi Ofset, Yogyakarta 